\title{
How are Government's Liability in Indonesia and Netherland?: Juridical-Normative Study with a Comparative Approach
}

\author{
Firzhal Arzhi Jiwantara $^{1}$, Karmal Maksudi ${ }^{2}$ \\ ${ }^{1}$ Law Faculty of Muhammadiyah, University Mataram, \\ ${ }^{2}$ Law Masters Program 42 Seventeen August 1945 Surabaya
}

\begin{abstract}
Indonesian liability is included as the Government's responsibility, namely as a compulsory compliance obligation of the state or government officials or other who carry out government's functions as a result of an objection, a law, a judicial review, which is submitted by a person, the community, an entity civil law either through court settlement or out of court. The purpose of this study was to compare the responsibilities between Indonesia Government with Netherlands. The study used juridical-normative with a comparative approach based on the statute approach as the object of discussion. This case as a form of Governments' responsibility both in civil and administrative cases. While accountability of the Government in Netherlands (civil law system) are known with several teachings regarding civil liability, namely: Accountability based on mistakes (schuldaansprakelijkheid), liability based on an error with an inverse proof load (schuldaansprakelijkheid met omkering van de bewijslast), and liability based on risk (risicoaansprakelijkheid). In the Dutch legal system, the equivalent of strict liability is risk-aansprakelijkheid. Responsibility based on risk is a form of responsibility that is not based on the elements of error for the following activities: hazardous material management; waste management installation; and drilling mining activities. The Defendant is free from responsibility based on risk, if: loss arises as a result of war; losses due to extraordinary natural events; losses due to obeying authority orders; losses due to victim's actions; losses due to third party actions.
\end{abstract}

Keywords: Comparison, Government Liability, Indonesia, and Netherlands.

\section{Introduction}

Government as implementing the legislation certainly has the main task and function for ensuring the creation of public welfare based on the established rules and assignment of bestuurzorg or tasks in the form of public services. State government based on the constitution is a reflection of the rule of law. The concept of a prosperous and society are a concept that includes responsive justice values, which support the objective of the rule of law. The government as the organizer is also demanded to be more flexible towards the problems that occur in the community so that the result of legal products do not harm and guarantee fairness. Furthermore, regarding the state's liability in the air navigation implementation, the state's liability could be divided into two, namely liability under the administrative law and liability under the international law $^{2.3}$. That article said: "Delegation is the delegation of authority from a higher Government Agency and/ or Government Officer to a lower Government Agency and/or Government Officer with responsibilities and accountability is fully transferred to the recipient of the delegation". Even though UUAP distinguishes into two, it does not try to determine the definition of the two. Responsibility is paired with another responsibility while the equivalent responsibility is a liability. It turns out, that there are also those who equate the notion of accountability with accountability which implies the understanding: willingness to sue the responsibilities that have been given to those who accept and are willing to carry out certain tasks. Understanding Accountable means the same as responsible, answerable. Furthermore, the meaning of word accountable, according to the 
Contemporary English-Indonesian Dictionary, is responsible. As in writings relating to the contractual relationship between the nurse and her client, many contain a charge of accountability that is equated with accountability. Based on the description above, the researcher will discuss the Liability of the Government in Indonesia and compare it with the Liability of the Government in Netherlands ${ }^{4,5}$.

\section{Material and Method}

Type of research used in this study is juridicalnormative research, which is scientific research procedures in finding truth based on the study of legal science in terms of normative which is focused on analyzing the application of norms in positive law ${ }^{2,3}$. The approach used is a Comparative Approach, which compares the accountability of the Indonesia Government with Netherlands and the statutory approach, which is used in the contents of legal regulations to examine existing problems. Legal research ${ }^{3}$ is a distinctive character of jurisprudence ${ }^{3,4}$, to address legal issues that are studied in this research. In legal research, we need a method that is related to the problem to be examined. Source and Type of Data Material: Primary Data, which is legal material that consists of laws and regulations relating to issues raised regarding the comparison of government responsibilities in Indonesia and Netherlands. Secondary data, namely legal material obtained from books, journals, opinions of scholars, and symposiums conducted by experts related to issues raised in research on comparative accountability of governments in Indonesia and Netherlands. Tertiary Data, i.e. legal materials that provide meaningful instructions or explanations for primary and secondary legal materials, such as legal dictionaries in the fields of Administrative Law and Constitutional Law.

Finding: Responsibility in the sense of liability is defined as accountability which is a translation of liability/ aanspralijkheid, a specific form of responsibility. Peter Mahmud Marzuki's opinion is related with the civil law experts' opinion in the early 20th century, namely $\mathrm{JH}$ Niewenhuis, said that accountability is an obligation to bear compensation as a result of violating the norm. Violating actions of these norms can occur due to: first the act against the law, secondly the interpretation. Furthermore, Nieuwenhuis explained that accountability was based on two pillars, namely violation of law and error. Referring to Niewenhuis ${ }^{5}$ 's opinion, an understanding can be drawn that the accountability can occur because First of the Law; it means that a particular person/party is declared liable not because of his mistake, but he issued because of the provisions of the law. This kind of accountability is called a risk liability. The primary data used by the Swiss Reinsurance Company is compiled by governments or insurance associations in individual countries.

\section{Discussion}

The concept of this accountability can we examine based on Peter Mahmud Marzuki's opinion. He said that the definition of responsibility in the sense of liability is defined as accountability which is a translation of liability/aanspralijkheid, a specific form of responsibility. According to him, the definition of accountability refers to the position of a person or legal entity deemed to have, to pay a form of compensation after a legal event or legal action. A person, for example, must pay compensation to another person or legal entity for having committed an unlawful act (onrechtmatige daad) which causing harm to that person or other legal entity. The term of accountability is within the scope of private law ${ }^{5,6,7,8}$. Peter Mahmud Marzuki's opinion is related with the civil law experts' opinion in the early 20th century, namely $\mathrm{JH}$ Niewenhuis, said that accountability is an obligation to bear compensation as a result of violating the norm. Violating actions of these norms can occur due to: first the act against the law, secondly the interpretation. Furthermore, Nieuwenhuis explained that accountability was based on two pillars, namely violation of law and error. Referring to Niewenhuis ${ }^{5}$ 's opinion, an understanding can be drawn that the accountability can occur because First of the Law; it means that a particular person/party is declared liable not because of his mistake, but he issued because of the provisions of the law. This kind of accountability is called a risk liability. The second mistake was caused by an agreement between the parties that harmed one of the parties as regulated in Article 1365 of the Civil Code (unlawful acts). This kind of liability is known as accountability based on the element of error and in its development also because the proof is a liability based on the presumption of guilt. The responsibilities and accountability of government positions in the public sector are outlined in the legislation form (regulation), policy regulations (beleidsregel), and state administrative decisions (beschikking), as well as factual actions (feitelijke hendeling), in the form of government actions that are resolved through institutions different courts, if the government's actions cause harm to citizens. 
According to Toshiro Fuke $6,7,8,9$, from the historical aspect of the development of accountability to the state, there are 6 (six) development phases mentioned as follows: since the liberation theory, state liability, non-authoritative activities, the welfare state, the case of compulsory acquisition of property (land in particular), and loss/injury that caused by natural distorter. In a broad sense, state liability is that the state will compensate for any loss that arises and occurs, which is caused directly or indirectly, materially or mentally to the citizens, as a result of using public authority. Premiums are disaggregated into two broad classes: life and propertyliability insurance ${ }^{10,11,12,13}$

The primary data used by the Swiss Reinsurance Company is compiled by governments or insurance associations in individual countries. Recognizing the different valuation bases adopted in different countries, the Swiss Reinsurance Company adjusts the primary data to attain consistency. In particular, an attempt is made to produce premium figures that are gross of reinsurance and gross of commissions ${ }^{14,15}$. Even though such a valuation basis more closely reflects the demand for insurance rather than the supply, the researcher ensure that data are consistent enough to justify the international comparative analysis adopted in this paper ${ }^{5,16,17}$. The definition of criminal liability is proposed by Simons as a psychic state so that the application of a criminal code from a public and private point of view is considered appropriate. Still, according to Simons, the basis of responsibility in criminal law is a certain psychic circumstance in the person committing a criminal act and relationship between the circumstances and the deeds that have been done in such a way that person can be reproached for doing the deed, So it can be deduced that the core of accountability in criminal law as proposed by Simons is: the first one, a person with psychic or mental condition; and second one about the relationship between psychological condition likely stress and self esteemand actions ${ }^{17,18,19,29,30}$. The term of Governmental Liability is often interchangeable with the term State Liability, for example, JJ Van Der Gouw, et al. (1997) entitled Government Liability in Netherlands said that both the states, central and regional governments, the officer council and other subordinates that have governmental duties which are classified as legal persons who can be held accountable both in civil law and law administration if unlawful actions $^{7}$. Acts of public law (for example in the form of dismissal) article 131 were used, according to him because the use of Article 839 of the German Civil Code which is the personal responsibility of officials (official personality) is often unsatisfactory, so that in turn can lead to public distrust of the government ${ }^{8}$. In general, the definition of Government Responsibility is the compulsory compliance obligation of the state or government or government officials or other officials who carry out government functions as a result of an objection, lawsuit, judicial review, which is submitted by a person, the public, a good legal entity through court settlement or out of court for fulfillment in the form of (a) payment of a sum of money (subsidies, compensation, benefits, etc.); (b) issue or cancel/revoke a decision or regulation, and (c) other actions that fulfill their obligations, for example, to carry out more effective and efficient supervision, prevent danger to humans or the environment, protect citizens' property, manage and maintain public facilities and infrastructures, impose sanctions for violations and so on ${ }^{9,20,21,23}$. The understanding is clear that governmental liability is more emphasized on civil and administrative liability, while criminal liability is attached to the personal acts of the officials concerned, for example, corruption, murder, adultery, etc. by criminal provisions. In the context of governmental liability, in the field of civil law is generally based on an action against the law committed by the authorities (onrechmatige overheidsdaad or unlawful acts of the government) as determined in Article 1365 of the Civil Code.

The settlement of this civil action can be done through the court or outside the court, namely through the ADR mechanism (al: mediation and arbitration) The procedure for civil litigation pursuant to Article 1365 of the Civil Code is intended for the government to be civilly responsible in the form of compensation payments, so it must be proven: (a) the government's actions are against the law; (b) truly guilty; (c) the claimant (community/ private legal entity) did indeed suffer a loss; (d) the loss is the result of government actions. Governmental responsibility in the scope of administrative law is based on unlawful acts of the government caused by the actions of the government in the form of State Administration Decree made in violation/contravention, at first the laws and the prevailing regulations, the second is contrary to the general principles of good governance as stipulated in Law No. 28 of 1999 concerning Administration of a Country that is Clean and Free of Corruption, Collusion, and Nepotism $10,24,25,26,27,28$ 


\section{Conclusion}

The definition of accountability refers to the position of a person or legal entity deemed to have, to pay a form of compensation after a legal event or action. The liability in Indonesia is included as the Government's responsibility, namely as a compulsory compliance obligation of the state or government or officials government who carry out government functions as a result of an objection, suit, judicial review, submitted by a person, community, body civil law either through court settlement or out of court.

Acknowledgment: Researcher's acknowledgment for the greatest help received from the Faculty of Law, University of Muhammadiyah Mataram.

\section{Conflict of Interest: No}

Source of Funding: Self-funding

Ethical Clearance: This study was approved by the institutional review board of Ethical Approval The research received a certificate from the University of Muhammadiyah Mataramethical permission

\section{References}

1. Sinaga., P. "The Relationship Between Power and Pouvoir Discretionnaire in Government Administration in SF Marbun et al, Dimensions of Legal Thinking in State Administration, Yogyakarta, UII Press. 2001, p. 73.

2. Lestari, EP . Tthe Delegation of State Sovereignty Over Air Space in the Implementation of Air Navigation: the Analysis of the Agreement Between Indonesia and Singapore on Management of the Batam and Natuna Flight Information Region', Fiat Justisia 2018, 11 (2), pp. 173-199. doi: 10.25041/ fiatjustisia.v11 no2,813.

3. Retno Ningsih, SD, Supanto, S. and Latifah, E. Corporation As the Actors of Fisheries Crime in Indonesia', Journal of Legal Dynamics 2018, 18 (2), p. 208. doi: 10.20884/1.jdh.2018.18.2.2067.

4. Jhony., I., Theory and Methodology of Normative Legal Research, Malang 2006, p. 57.

5. Marzuki, PM Legal Research, Jakarta: Prenada Media 2008 p. 29-33.

6. Brugink JJ, Rechtsreflecties, Interpreting Arif Sidartha, Bandung: Citra Aditya Bakt 1995. i, p. 213-218.
7. Nieuwenhuis JH, Hoofdstuken verbintenissenrecht, translation of Djasadin Saragih, Surabaya, 1985, p.118.

8. Sudiarto.. Government Sues for Aircraft Accident in Indonesia. Amanna Gappa 2012. Vol. 20 Number 3: 273-287.

9. Erwiningsih, W The Role of Law in Responsibility for Government Actions, Journal of Legal Studies 2006, Vol. 9, No. 2, FH UII Jogjakarta, 2006

10. Depenheuer, Governmental Liability, in "Comparative Studies on Governmental Liability in East and Southeast Asia", edited by Yong Zhang, Kluwer Law International p. 173

11. Erwiningsih, Role of Law in Accountability 1999, p. 191

12. Article 53 of Law no. 9 of 2004 concerning Amendment to Law No. 5 of 1986 concerning State Administrative Court, along with its explanation.

13. Article $24 \mathrm{C}$ of the 1945 Constitution.

14. Santosa, MA, Implementation of the Strict Liability Principle in the Environmental Field, ICEL, Jakarta 1997, p. 23

15. Malau, P., Syahrin A.. An Obligation of Corporate Criminal Liability in the Case of NonImplementation of Occupational Health and Safety (OHS). Jarle 2020 Vol 11 (1). https://doi. org/10.14505//jarle.v11.1(47).16

16. Beenstock, M., Dickinson, G. and Khajuria, S. 'The Relationship between Property-Liability Insurance Premiums and Income: An International Analysis. The Journal of Risk and Insurance 1988, pp. 259. doi: $10.2307 / 253327$.

17. Chasani, M. 'Corporate Criminal Liability in Indonesia on the Perspective of Comparison', IJCLS Indonesian Journal of Criminal Law Studies 2017,2 (2), pp. 144-154. doi: 10.15294/ijcls. v2i2.12322.

18. Gunawan, J. 'Controversy on Strict Liability in Consumer Protection Law', Veritas et Justitia 2018, 4 (2), pp. 274-30. doi: 10.25123/vej.3082

19. Ariani, D. 'the Effectiveness of Climate Change Litigation As a Venue to Uphold State Climate Change Obligations in Indonesia', Indonesian Journal of International Law 2019, 16 (2), pp. 210234. doi: 10.1017/CBO9781107415324.004.

20. Marano, V., Tallman, S. and Teegen, HJ 'The liability of disruption', Global Strategy Journal 
2020, 10 (1), pp. 174-209. doi: 10.1002/gsj.1366.

21. Mustikasari, E., Hartiwiningsih and Muryanto, YT 'Implementing the "Legal Reality Model" Into Indonesian Corporate Criminal Liability', Advances in Social Science, Education and Humanities Research, 358 (Icglow) 2019. pp. 127130. doi: 10.2991/icglow-19.2019.32.

22. Nugraha, X., Murti, K. and Putri, S. 'Third Parties' Legal Protection over Agreed Authorized Capital Amount by Founders in Limited Liability Companies', Legal Lantern 2019, 6 (2), p. 173. doi: 10.19184/ejlh.v6i1.9676.

23. Sadino, Surono, A. and Arifin, MZ'Legal analysis on application of strict liability in palm oil plantation fire cases in Indonesia', IOP Conference Series: Earth and Environmental Science 2020, 504 (1). doi: 10.1088/1755-1315/504/1/012026.

24. Sonia, V. and Sunyowati, D. 'The state liability of plastic waste dumping in Indonesia', Utopia y Praxis Latinoamericana 2020, 25 (Extra1), pp. 493-505. doi: 10,5281/zenodo.3784901.

25. Tazza Ulima, D. 'The Criminal Liability of the Defamation Perpetrators Against The President or Vice President After Having the Constitutional Court Decision Number 013-022/Puu-Iv/2006', Journal of Legal Discourse and Universitas Merdeka surabaya 2018, Vol 11 (2), pp. 46-63.
26. Universityjalan, S. et al'Strict Liability Principle: Consumer Protection from Hidden Defective Products in Indonesia', Sriwijaya Law Review 2020, 4 (1), pp. 109-123. doi: 10.28946/slrev.Vol4. Iss2.295.pp109-123.

27. Wibisana, AG 'The many faces of strict liability in Indonesia's wildfire litigation', Review of European, Comparative and International Environmental Law 2019, 28 (2), pp. 185-196. doi: 10.1111/reel.12284.

28. Wibisana, AG and Marbun, AN. Corporate Criminal Liability in Indonesia Anti-Corruption Law: Does It Work Properly?', Asian Journal of Law and Economics 2018, 9 (1), pp. 1-15. doi: 10.1515/ajle-2017-0029.

29. Suhron M, A Yusuf, R Subarniati. Assessment of Stress Reactions and Identification of Family Experiences in Primary Care Post Restrain Schizophrenia in East Java Indonesia. Mix Method: Sequential Explanatory. Indian Journal of Public Health Research \& Development. 2018;10(12):1849-1854

30. Suhron, M. "Asuhankeperawatanjiwakonsepself esteem/Care of Mental Nursing The concept of self-esteem". Jakarta: Mitra Wacana Media; 2017 